\title{
Jaminaea angkorensis gen. nov., sp. nov., a novel anamorphic fungus containing an S943 nuclear small-subunit rRNA group IB intron represents a basal branch of Microstromatales
}

\author{
Matthias Sipiczki and Erika Kajdacsi
}

Correspondence

M. Sipiczki

lipovy@tigris.unideb.hu

\author{
Department of Genetics and Applied Microbiology, University of Debrecen, PO Box 56, \\ 4010 Debrecen, Hungary
}

Microstromatales, Exobasidiales and Entylomatales are related orders of the class Exobasidiomycetes that comprise species lacking teliospores and mostly occur on woody bushes and trees (Bauer et al., 1997; Begerow et al., 2006). The class Exobasidiomycetes belong to the basidiomycetous subphylum Ustilaginomycotina, containing species that are usually dimorphic, having both yeast and hyphal phases (Begerow et al., 2006). Ustilaginomycota also contains anamorphic species such as members of Acaromyces, Malassezia, Meira, Rhodotorula, Tilletiopsis or Sympodiomycopsis (Boekhout et al., 2003, 2006; Xu et al., 2007; Weijman et al., 1988). The latter genus is classified within the Microstromatales and accommodates a species, Sympodiomycopsis paphiopedili (Sugiyama et al., 1991; Suh \& Sugiyama, 1994), which secretes an antifungal glycolipid into the culture medium (Kulakovskaya et al., 2004). Antifungal antagonism is a property of numerous yeast genera and can be exploited in bioprotection of crops and

\section{Abbreviation: ITS, internal transcribed spacer.}

The GenBank/EMBL/DDBJ accession numbers for the sequences of isolate $\mathrm{C}^{\mathrm{T}} \mathrm{b}^{\top}$ (CBS 10918 ) are EU587489 (D1/D1 domain of the large-subunit rRNA gene), EU604148 (18S rRNA gene), EU604147 (ITS1-5.8S rRNA gene-ITS2) and EU604149 (group IB intron).

Figures showing a CLUSTAL alignment of the rRNA group I introns of Ustilago maydis and strain $\mathrm{C} \mathrm{b}^{\top}$ and a maximum-likelihood analysis of the S943 nuclear small-subunit rRNA group IB intron sequences are available as supplementary material with the online version of this paper. horticultural produce (for a review see Spadaro \& Gullino, 2004). Certain antagonistic yeasts are pigmented and their antimicrobial activity can be a consequence of the pigment synthesis (Sipiczki, 2006). In a yeast isolation project intended to identify novel pigmented antagonistic yeasts, we isolated two strains from fallen leaves that produced pink colonies. Although they failed to show antimicrobial activities under laboratory conditions, their preliminary examination indicated that they might be interesting from a taxonomic point of view. In this paper we describe their morphology, taxonomy and phylogenesis and propose a species name for them.

\section{Isolation and phenotypic characterization of yeast strains}

Fallen leaves were collected from two different localities of the world heritage site Angkor, Cambodia in 2006. The collected plant material was macerated in sterile water and samples were streaked on YPGA (1\% yeast extract, $1 \%$ peptone, $2 \%$ glucose, $2 \%$ agar, w/v) plates. After incubation for 14 days at $25{ }^{\circ} \mathrm{C}$, individual yeast colonies were isolated. Two isolates $\left(\mathrm{C}^{2} \mathrm{~b}^{\mathrm{T}}\right.$ and $\left.\mathrm{C} 6 \mathrm{~b}\right)$ were selected for further examination. Both strains produced smooth, slightly pink colonies on YPGA medium, which upon prolonged incubation gradually became darker with venose and occasionally warty surfaces, and slightly eroded margins with occasional farinose sectors (Fig. 1a). The 


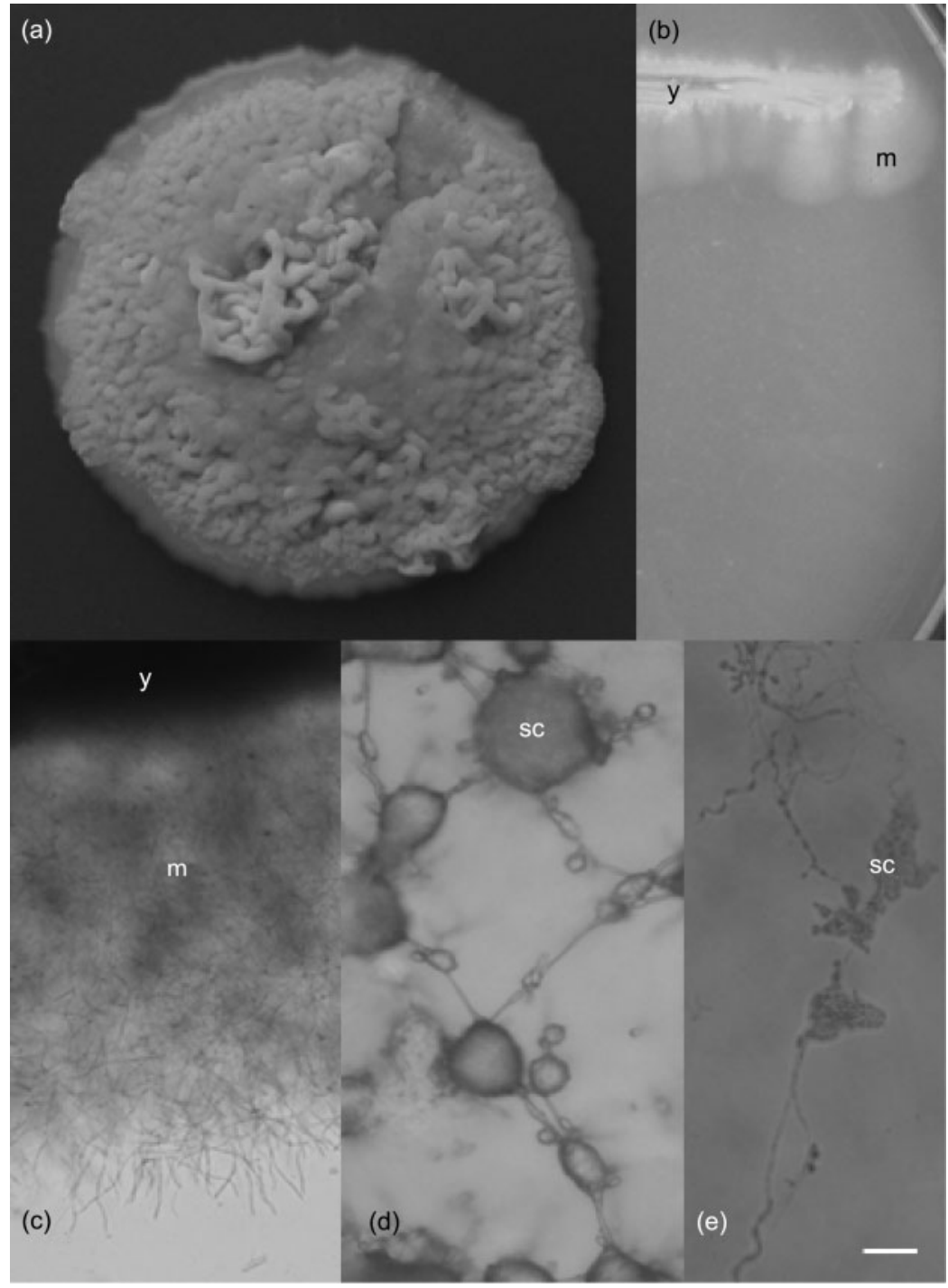

Fig. 1. Growth of strain $\mathrm{C} \mathrm{b}^{\top}$ (Jaminaea angkorensis gen. nov., sp. nov.) on solid media. (a) Yeast colony on YPGA after 14 days. (b) Dimorphic colony on CMA after 1 month. (c) Invasive mycelium. (d and e) Formation of satellite yeast colonies (hypha-toyeast transition) in the substrate colonized by the invasive mycelium. $y$, Yeast colony; $\mathrm{m}$, mycelium; sc, satellite yeast colony. Bar, $100 \mu \mathrm{m}$. colonies contained yeast cells of variable shape and size, propagating by apical budding (Fig. 2a). Cell morphology was examined by using phase-contrast microscopy. Photographs were taken using an Olympus BH-2 microscope. Around and below the yeast colonies, slowly growing invasive mycelium was observable, particularly when CMA (Corn Meal Agar; van der Walt \& Yarrow, 1984) medium was used (Fig. 1b-e). The mycelium grew towards uncolonized parts of the medium (Fig. 1b). A similar phenomenon was described in Schizosaccharomyces japonicus, where the hyphal extension was directed by a gradient of nutrients between the colonized (shortage of nutrients) and uncolonized (rich in nutrients) parts of the substrate (Sipiczki et al., 1998). The mycelial phase mainly consisted of long hyphae producing apical conidia-like cells on sterigma-like protuberances (Fig. 2c) that either developed into new hyphae or produced small 'satellite' colonies (Fig. 1d, e) consisting of individual yeast cells or pseudo-hypha-like chains of unseparated yeast cells
(Fig. 2d, e). Occasionally, septa were visible in longer hyphae (true mycelium) (Fig. 2b). The septate hyphae branched at certain septa. The isolates were further subjected to tests standard to yeast taxonomy using methods described by van der Walt \& Yarrow (1984). The results of the physiological and growth tests are shown in Table 1. No sporulation was detected in the cultures even after prolonged incubation.

\section{Sequence analysis of the D1/D2 domain of the 26S rRNA gene and the ITS1-5.8S-ITS2 region}

To reveal the taxonomic affiliation of the isolates, we isolated nuclear DNA from overnight cultures grown in YPG broth and amplified the chromosomal regions coding for the D1/D2 domain of the LSU 26S rRNA gene with primers NL-1 and NL-4 (O'Donnell, 1993), as described by Sipiczki (2003). The same primers were used for sequencing of the fragments obtained. The sequences of the 


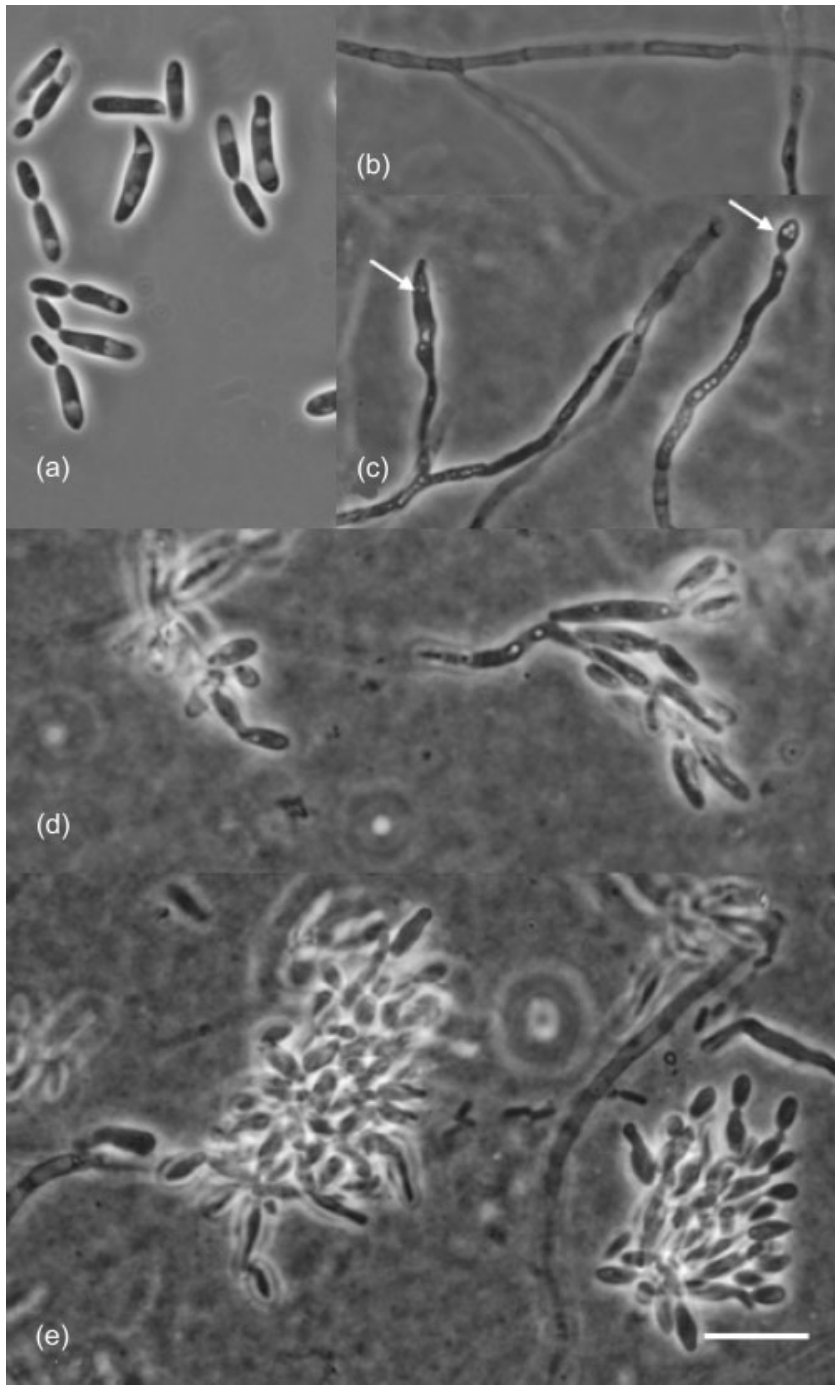

Fig. 2. Microscopic morphology of strain $\mathrm{C}_{5} \mathrm{~b}^{\top}$ (Jaminaea angkorensis gen. nov., sp. nov.). (a) Budding yeast cells propagating in the liquid medium YPG. (b) Invasive septate hypha branching at a septum. (c) Hyphae producing apical conidia-like cells (marked by arrows). ( $d$ and e) Pseudo-hypha-like chains of budding yeast cells establishing satellite yeast colonies at the tips of invasive hyphae. Bar, $10 \mu \mathrm{m}$.

isolates proved to be identical. A megablast similarity search in the NCBI database (http://www.ncbi.nlm.nih. gov.blast) revealed $97 \%$ similarity between them and the sequence of the unspecified organism Sympodiomycopsis sp. LM418 (12 nucleotide differences). However, they differed from the corresponding sequence of the type strain of Sympodiomycopsis paphiopedili, the only characterized species of the genus, by $6 \%$ (at 35 nucleotides). Somewhat higher similarities (95\%; differences: $27-30$ nucleotides; gaps: 1-7 nucleotides) were detected with the D1/D2 domain sequences of various strains of three Rhodotorula ( $R$. phylloplana, R. hinnulea, R. baccarum), one Microstroma (M. juglandis) and three Quambalaria (Q. pitereka, Q. cyanescens, Q. eucalypti) species, all belonging to Microstromatales. As none of these species differ in the D1/D2 sequence from the rest of the group by more than $5 \%$, the difference between them and the Cambodian isolates strongly suggests that the latter represent a novel species. A previous comparative sequence analysis of large groups of basidiomycetous yeasts demonstrated that the D1/D2 and internal transcribed spacer (ITS) regions are suitable for species identification (Fell et al., 2000; Scorzetti et al., 2002). In ascomycetous yeasts, a minimum of $1 \%$ divergence in the D1/D2 domain of the $26 \mathrm{~S}$ rRNA gene is usually sufficient to resolve individual ascomycetous yeast species (Kurtzman \& Robnett, 1998).

To determine the phylogenetic position of the Cambodian isolates, we derived phylogenetic trees from the D1/D2 domain sequences of isolate $\mathrm{C}^{\mathrm{b}} \mathrm{b}^{\mathrm{T}}$, the corresponding Microstromatales sequences available in the NCBI database and certain additional species representing related basidiomyceteous orders. For multiple alignment of sequences, the CLUSTAL W 1.7 (Thompson et al., 1994) and the MAFFT version 6 (Katoh \& Toh, 2008) algorithms were used. The phylogenetic analysis was carried out using the FitchMargoliash, maximum-likelihood, neighbour-joining and DNA parsimony methods of the PHYLIP software package, version 3.67 (Felsenstein, 2007). Confidence limits for phylogenetic trees were estimated from bootstrap analysis (1000 replications; SEQBOOT and CONSENSE of the PHYLIP package). Phylogenetic trees were visualized with the TreeView program (Page, 1996). In the trees obtained (example in Fig. 3), strain $\mathrm{C} \mathrm{b}^{\mathrm{T}}$ and the uncharacterized Sympodiomycopsis sp. LM418 formed a clade with the Microstromatales species and appeared as a basal branch with high bootstrap support (ranging from 89 to $98 \%$, depending on the method used).

\section{Sequence analysis of the 18S rRNA gene and the ITS1-5.8S-ITS2 region}

The chromosomal segment coding for the small-subunit $18 \mathrm{~S}$ rRNA gene, ITS1, 5.8S rRNA gene and ITS2 was amplified with the primers Fungi-18S-up (TTGTCTCAAAGATTAAGCCATGCATGTCTAA) (Zimmer et al., 2006) and ITS4 (TCCTCCGCTTATTGATATGC) (White et al., 1990). Using these primers we could only sequence the ends of the fragment. For sequencing of the entire fragment we also used the internal primers Sin1 (GACAGTTGGGGGCATTAGTAT) and Sin2 (AAAGGGCAGGGACGTAATCAA).

The phylogenetic analysis of the ITS1-5.8S-ITS2 region confirmed the basal position of strain $\mathrm{C} 5 \mathrm{~b}^{\mathrm{T}}$ with even higher bootstrap values than in the D1/D2 analysis. The D1/D2 and ITS trees were also congruent in showing no close phylogenetic affiliation for this branch with any known genera of Microstromatales. We therefore propose a new genus, Jaminaea Sipiczki \& Kajdacsi gen. nov., to accommodate these organisms and a novel species, Jaminaea angkorensis Sipiczki \& Kajdacsi sp. nov., for the Cambodian isolates. 


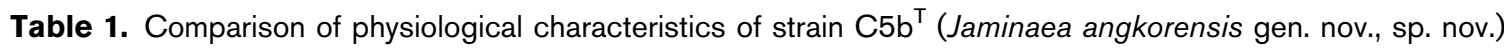
and Sympodiomycopsis paphiopedili

+, Growth; -, no growth; d, delayed growth; w, weak growth. Both species were positive for assimilation of D-glucose, L-sorbose, D-xylose, D-arabinose, sucrose, maltose, cellobiose, raffinose, melezitose, glycerol, L-arabinitol, D-glucitol, D-mannitol, meso-inositol, succinate, citrate, ethanol and nitrate. Both species grew on vitamin-free medium, did not grow at $37{ }^{\circ} \mathrm{C}$ and were negative for assimilation of arbutin and production of acetic acid.

\begin{tabular}{|lcc|}
\hline Characteristic & Strain $\mathbf{C 5}^{\mathbf{T}}$ & Sympodiomycopsis paphiopedili $^{*}$ \\
\hline Assimilation of carbon compounds & & $\mathrm{d}$ \\
D-Galactose & + & $\mathrm{d}$ \\
D-Ribose & + & $\mathrm{d}$ \\
D-Arabinose & + & - \\
L-Rhamnose & $\mathrm{d}$ & + \\
Trehalose & $\mathrm{d}$ & - \\
Salicin & $\mathrm{d}$ & $\mathrm{d}$ \\
Melibiose & + & $\mathrm{d}$ \\
Lactose & - & - \\
Inulin & + & - \\
Starch & + & + \\
Erythritol & - & $\mathrm{d}$ \\
Ribitol & + & $\mathrm{d}$ \\
Xylitol & - & $\mathrm{W}$ \\
D-Glucuronate & $\mathrm{d}$ & - \\
D-Galacturonate & $\mathrm{W}$ & - \\
DL-Lactate & + & $\mathrm{d}$ \\
1,2-Propanediol & + & \\
Assimilation of nitrogen compounds & & + \\
Nitrite & - & - \\
L-Lysine & + & \\
Other tests & + & - \\
Methanol & $\mathrm{W}$ & + \\
Growth in $60 \%$ glucose & & \\
\hline
\end{tabular}

${ }^{\star}$ Data from CBS (http://www.cbs.knaw.nl/yeast/BioloMICS.aspx).

A megablast search in the NCBI database found 95-97\% sequence similarity with all species identified in the D1/D2 and ITS searches. However, it also revealed a 392nucleotide long intron starting at nucleotide 1101, which corresponds to position 943 in the Escherichia coli 16S numbering. In the $18 \mathrm{~S}$ phylogenetic trees inferred after the exclusion of this intron and ambiguously aligned regions of the sequences, the Cambodian isolate $\mathrm{C} 5 \mathrm{~b}^{\mathrm{T}}$ appeared as a distinct branch of Microstromatales again, although not as basal as in the D1/D2 and ITS trees. We also constructed a Fitch-Margoliash tree from combined D1/D2+18S+ ITS1-5.8S-ITS2 sequences of species shown in Fig. 3, for which all three regions were available. Strain $C 5 b^{T}$ grouped with the Microstromatales species as a basal branch with a bootstrap value of $100 \%$. Although the molecular phylogenetic analyses unanimously indicate its association with the Microstromatales, the exact taxonomic placement of Jaminaea (e.g. relationship to families within the Microstromatales) requires a comprehensive cytological and molecular biological investigation involving representatives of the major genera of the Microstromatales, Entylomatales and Exobasidiales. Sequencing of genes encoding phylogenetically conserved proteins such as $\beta$ tubulin (Begerow et al., 2004), the RNA polymerase II subunit Rpb2, and the translation elongation factor Tef1 (Matheny et al., 2007), etc. could be particularly useful. Electron microscopic examination of the septal structures in Jaminaea hyphae would provide cytological data important for the elucidation of the relationship of the new genus to the Exobasidiales, in which the septal pores and the caps enclosing the pores are larger than those in the Microstromatales (Bauer et al., 1997; Begerow et al., 2001).

\section{Sequence analysis of the intron of the 18S rRNA gene}

When the intron was used as query sequence, a BLASTN search in the NCBI database identified similarity with many group I introns. All but one of the most similar 15 hits (similarity: 74-86\%; E-value: $\mathrm{e}^{-31}-\mathrm{e}^{-54}$ ) were sequences of Ustilagomycotina species. Supplementary Fig. S1 (available in IJSEM Online) shows the CLUSTAL alignment of the C5b ${ }^{\mathrm{T}}$ intron with the intron of Ustilago maydis, for which a secondary structure has been published (De Wachter et al., 


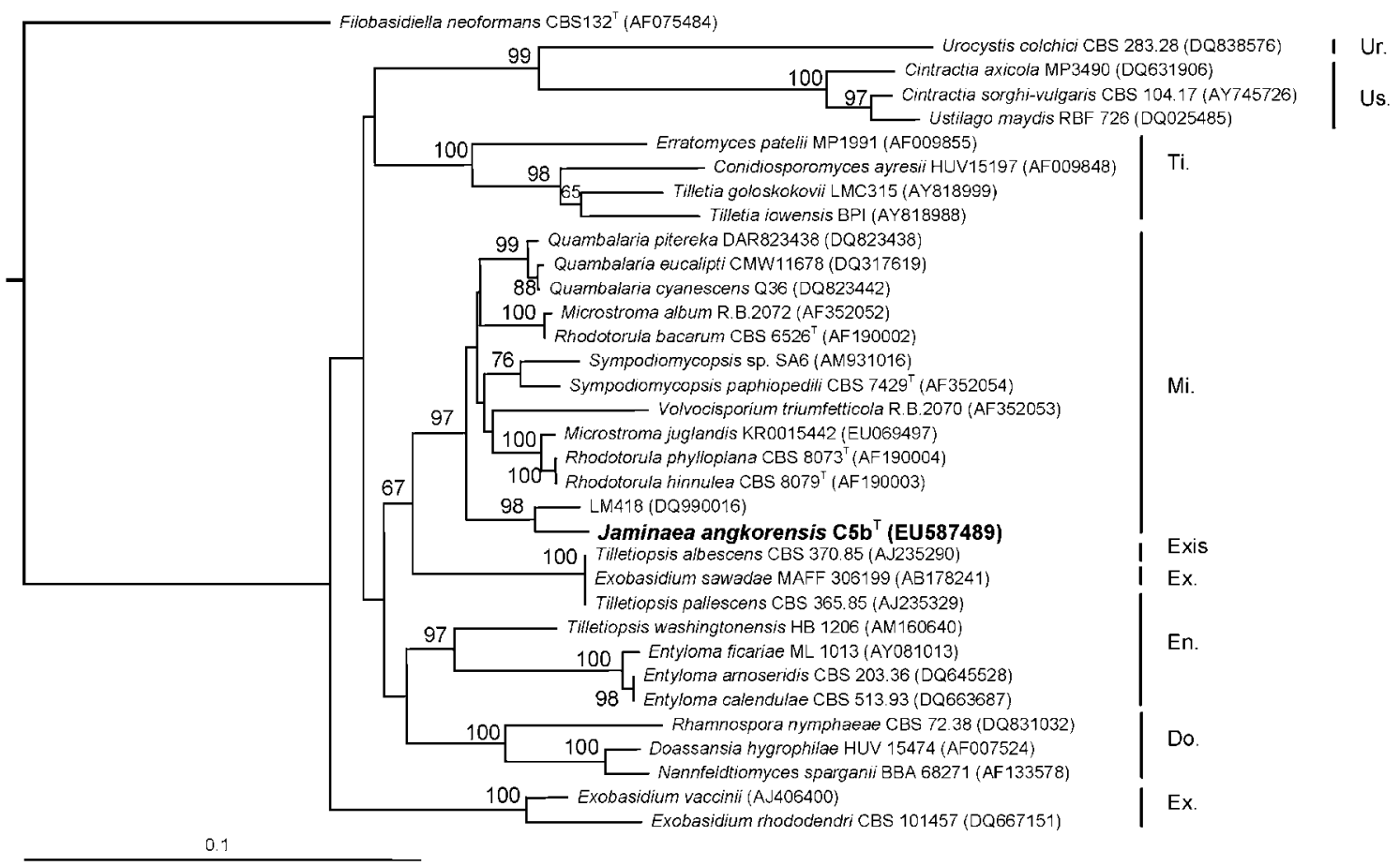

Fig. 3. Phylogenetic analysis of the chromosomal sequences coding for the $D 1 / D 2$ domains of the large-subunit (26S) RNA gene by using the Fitch-Margoliash distance method. Outgroup: Filobasidiella neoformans (Cryptococcus neoformans). GenBank accession numbers are given in parentheses. Do., Doassantiales; En., Entylomatales; Ex., Exobasidiales; Exis., Exobasidiomycetidae incertae sedis; Mi., Microstromatales; Ti., Tilletiales; Ur., Urocystales; Us., Ustilaginales. Numbers at branch points are bootstrap probability values (1000 replicates). Bootstrap values of less than $50 \%$ are not given. Bar, 1 substitution per 10 nucleotides.

1992). It contains all conserved elements (P, Q, R and S) characteristic of group I introns (Cech, 1988). It can be classified as belonging to the subgroup $1 \mathrm{~B}$ because its $\mathrm{R}$ element is immediately followed by $\mathrm{P} 3$.

Group I introns are widespread in fungal genomes (Bhattacharya et al., 2005), but have not yet been reported in the Microstromatales. In view of this, the presence of the $1 \mathrm{~B}$ intron in the 18S rRNA gene of strain $\mathrm{C}^{\mathrm{b}} \mathrm{b}^{\mathrm{T}}$ can be interpreted as reinforcing the basal location of this fungus in the rRNA gene phylogenetic trees. It might represent an early stage of Microstromatales evolution characterized by the presence of an intron in the $18 \mathrm{~S}$ rRNA gene. The absence of sequences encoding homing endonucleases in strain $\mathrm{C}_{5} \mathrm{~b}^{\mathrm{T}}$ and related introns makes it likely that these introns are vertically inherited, and thus their phylogenetic analysis might give a clue for the origin of the $\mathrm{C} 5 \mathrm{~b}^{\mathrm{T}}$ intron. Therefore we inferred trees from the most similar intron sequences. The intron of strain $\mathrm{C}^{2} \mathrm{~b}^{\mathrm{T}}$ generated a distinct branch located basically to the common root of the Ustilaginales, Exobasidiales and Entylomatales in the MAFFT-maximum-likelihood tree (Supplementary Fig. S2 in IJSEM Online) and on a common branch with Exobasidiales, close to the node separating Exobasidiales from Entylomatales in the CLUSTAL-Fitch-Margoliash tree. The latter result suggests that it might have diverged from them after their separation from the Ustilaginales introns. However, because of the weak bootstrap support for certain branches (typical for these short sequences; Haugen et al., 2004), its history cannot be unambiguously reconstructed.

\section{Latin diagnosis of Jaminaea Sipiczki et Kajdacsi gen. nov.}

Genus anamorphicum e Microstromatales (Basidiomycota). Coloniis dimorphicis, primum zymoideis, cellulis fusiformibus, ad apicem e rachide acropetali proliferentibus; deinde hyphae septatae, hyalinae, ramosae, immersae et superficialae. Protuberantiae sterigmatideae saepe ad apicem formatae, e quibus catenae ramosae cellularum zymoticarum oriuntur. Ascosporae, basidiosporae, teliosporae, ballistofosporae nullae. Fermentatio nulla.

Typus Jaminaea angkorensis Sipiczki \& Kajdacsi.

\section{Description of Jaminaea Sipiczki \& Kajdacsi gen. nov.}

Jaminaea (Ja.mi.na.e'a. N.L. fem. n. Jaminaea pertaining to Jamina, the name of the township where Matthias Sipiczki stayed when writing this paper). 
Anamorphic genus, belonging phylogenetically to the Microstromatales (Basidiomycota). Colonies are dimorphic with initial yeast-like growth. Cells are fusiform showing polar budding on an acropetal rachis. Hyphae are septate, hyaline, branched, and grow both into the substrate and on its surface. Sterigma-like outgrowths, frequently formed on the tips of hypae, give rise to branched chains of cells.

The type species is Jaminaea angkorensis Sipiczki \& Kajdacsi.

\section{Latin diagnosis of Jaminaea angkorensis Sipiczki et Kajdacsi sp. nov.}

In medio liquido YPG post 2 dies ad $30{ }^{\circ} \mathrm{C}$, cellulae zymosae ovoidae vel fusiformae, 5-7 $\times 2-3 \mu \mathrm{m}$, singulae aut binae, utrinque sympodialer proliferentes. Annulus et sedimentum exiguum formantur. Coloniae in agaro YPGA et malti post 5 dies ad $30{ }^{\circ} \mathrm{C}$, subroseae, nitidae, planae, mollis, et margine glabrae; post 3 hebdomades roseae, convexae, superficie venosa vel cerebriformi, marginem versus sulcatae, partim synnematibus angustatis obtectae, sed etiam in sectoribus leves; margo integra vel modice erosa et sectoribus divisa. In agaro malti et in agaro farina Zea maydi confecto, post 2 hebdomades ad $25{ }^{\circ} \mathrm{C}$ hypae formantur. Mycelium partim superficiale et partim in substrato immersum. Hyphae 2-3 $\mu \mathrm{m}$ hyalinae, septatae. Fermentatio nulla. Proprietate physiologicae in Tabella 1 compositae. Typus $\mathrm{C}^{2} \mathrm{~b}^{\mathrm{T}}(=\mathrm{CBS}$ $10918^{\mathrm{T}}=$ CCY $\left.88-1-1^{\mathrm{T}}\right)$, isolatus ex folium putridum in Angkor World Heritage Site, Cambodia.

\section{Description of Jaminaea angkorensis Sipiczki \& Kajdacsi sp. nov.}

Jaminaea angkorensis (ang.ko.ren'sis. N.L. fem. adj. angkorensis pertaining to Angkor).

In liquid medium YPG after 2 days of incubation at $30{ }^{\circ} \mathrm{C}$, cells are oval or fusiform, $5-7 \times 2-3 \mu \mathrm{m}$, single or in pairs, with polar sympodial budding. Ring and a sparse sediment are present. On YPG agar, after 5 days at $30{ }^{\circ} \mathrm{C}$, colonies are light-pink coloured, glistering, flat, soft and have an entire margin. After 3 weeks, colonies are rose-red, convex, with the surface venose to cerebriform, radially furrowed near the margin, partly covered with tapered synnemata, but also with smooth sectors; margin entire or somewhat eroded and with sectors. On malt agar and on CMA after 2 weeks at $25{ }^{\circ} \mathrm{C}$, hyphae are formed. The mycelium grows on the surface but also invades the medium. Hyphae are $2-3 \mu \mathrm{m}$ in diameter, white and septate. Physiological characteristics are presented in Table 1.

The type strain is $\mathrm{C}^{\mathrm{b}} \mathrm{b}^{\mathrm{T}}\left(=\mathrm{CBS} 10918^{\mathrm{T}}=\mathrm{CCY} 88-1-1^{\mathrm{T}}\right)$, which was isolated from fallen and decaying leaves collected at the Angkor World Heritage Site, Cambodia.

\section{Acknowledgements}

The authors thank Ilona Lakatos for expert technical assistance. This work was supported by grant GND RET provided by the Hungarian National Office for Research and Technology.

\section{References}

Bauer, R., Oberwinkler, F. \& Vanky, K. (1997). Ultrastructural markers and systematics in smut fungi and allied taxa. Can J Bot 75, 1273-1314.

Begerow, D., Bauer, R. \& Oberwinkler, F. (2001). Muribasidiospora: microstromatales or exobasidiales? Mycol Res 105, 798-810.

Begerow, D., John, B. \& Oberwinkler, F. (2004). Evolutionary relationships among $\beta$-tubulin gene sequences of basidiomycetous fungi. Mycol Res 108, 1257-1263.

Begerow, D., Stoll, M. \& Bauer, R. (2006). A phylogenetic hypothesis of Ustilaginomycotina based on multiple gene analyses and morphological data. Mycologia 98, 906-916.

Bhattacharya, D., Reeb, V., Simon, D. M. \& Lutzoni, F. (2005). Phylogenetic analyses suggests reverse splicing spread of group I introns in fungal ribosomal DNA. BMC Evol Biol 5, 68.

Boekhout, T., Theelen, B., Houbraken, J., Robert, V., Scorzetti, G., Gafni, A., Gerson, U. \& Sztejnberg, A. (2003). Novel anamorphic mite-associated fungi belonging to the Ustilaginomycetes: Meira geulakonigii gen. nov., sp. nov., Meira argovae sp. nov. and Acaromyces ingoldii gen. nov., sp. nov. Int J Syst Evol Microbiol 53, 1655-1664.

Boekhout, T., Gildemacher, P., Theelen, B., Muller, W. H., Heijne, B. \& Lutz, M. (2006). Extensive colonization of apples by smut anamorphs causes a new post-harvest disorder. FEMS Yeast Res 6, 63-76.

Cech, T. R. (1988). Conserved sequences and structures of group I introns: building an active site for RNA catalysis - a review. Gene 73, 259-271.

De Wachter, R., Neefs, J.-M., Goris, A. \& Van der Peer, Y. (1992). The gene coding for small ribosomal subunit RNA in the basidiomycete Ustilago maydis contains a group I intron. Nucleic Acids Res 20, 12511257.

Fell, J. W., Boekhout, T., Fonseca, A., Scorzetti, G. \& StatzellTallman, A. (2000). Biodiversity and systematics of basidiomycetous yeasts as determined by large-subunit rDNA D1/D2 domain sequence analysis. Int J Syst Evol Microbiol 50, 1351-1371.

Felsenstein, J. (2007). PHYLIP (phylogeny inference package), version 3.67. Department of Genome Sciences, University of Washington, Seattle, USA.

Haugen, P., Reeb, V., Lutzono, F. \& Bhattacharya, D. (2004). The evolution of homing endonuclease genes and group I introns in nuclear rDNA. Mol Biol Evol 21, 129-140.

Katoh, K. \& Toh, H. (2008). Recent developments in the MAFFT multiple sequence alignment program. Brief Bioinform 9, 286-298.

Kulakovskaya, T. V., Shashkov, A. S., Kulakovskaya, E. V. \& Golubev, W. I. (2004). Characterization of an antifungal glycolipid secreted by the yeast Sympodiomycopsis paphiopedili. FEMS Yeast Res 5, 247-252.

Kurtzman, C. P. \& Robnett, C. J. (1998). Identification and phylogeny of ascomycetous yeasts from analysis of nuclear large subunit (26S) ribosomal DNA partial sequences. Antonie van Leeuwenhoek 73, 331371.

Matheny, P. B., Wang, Z., Binder, M., Curtis, J. M., Lim, Y. W., Nilsson, R. H., Hughes, K. W., Hofstetter, V., Ammirati, J. F. \& other authors (2007). Contributions of $r p b 2$ and tef1 to the phylogeny of mushrooms and allies (Basidiomycota, Fungi). Mol Phylogenet Evol 43, 430-451.

O'Donnell, K. (1993). Fusarium and its near relatives. In The Fungal Holomorph: Mitotic, Meiotic and Pleomorphic Speciation in Fungal Sytematics, pp. 225-233. Edited by D. R. Reynolds \& J. W. Taylor. Wallingford, UK: CAB International. 
Page, R. D. M. (1996). TreeView: an application to display phylogenetic trees on personal computers. Comput Appl Biosci 12, 357-358.

Scorzetti, G., Fell, J. W., Fonseca, A. \& Statzell-Tallman, A. (2002). Systematics of basidiomycetous yeasts: a comparison of large subunit D1/D2 and internal transcribed spacer rDNA regions. FEMS Yeast Res 2, 495-517.

Sipiczki, M. (2003). Candida zemplinina sp. nov., an osmotolerant and psychrotolerant yeast that ferments sweet botrytized wines. Int $J$ Syst Evol Microbiol 53, 2079-2083.

Sipiczki, M. (2006). Metschnikowia strains isolated from botrytized grapes antagonize fungal and bacterial growth by iron depletion. Appl Environ Microbiol 72, 6716-6724.

Sipiczki, M., Takeo, K., Yamaguchi, M., Yoshida, S. \& Miklos, I. (1998). Environmentally controlled dimorphic cycle in a fission yeast. Microbiology 144, 1319-1330.

Spadaro, D. \& Gullino, M. L. (2004). State of the art and future prospects of the biological control of postharvest fruit disease. Int $J$ Food Microbiol 91, 185-194.

Sugiyama, J., Tokuoka, K., Suh, S.-O., Hirata, A. \& Komagata, K. (1991). Sympodiomycopsis: a new yeast-like anamorph genus with basidiomycetous nature from orchid nectar. Antonie van Leeuwenhoek 59, 95-108.

Suh, S.-O. \& Sugiyama, J. (1994). Phylogenetic placement of the basidiomycetous yeasts Kondoa malvinella and Rhodosporidium dacryoidum, and the anamorph yeast Sympodiomycopsis paphiopedili by means of $18 \mathrm{~S}$ rRNA gene sequence analysis. Mycoscience 35, 367375.

Thompson, J. D., Higgins, D. G. \& Gibson, T. J. (1994). CLUSTAL W: improving the sensitivity of progressive multiple sequence alignment through sequence weighting, position-specific gap penalties and weight matrix choice. Nucleic Acids Res 22, 4673-4680.

van der Walt, J. P. \& Yarrow, D. (1984). Methods for the isolation, maintenance, classification and identification of yeasts. In The Yeasts: a Taxonomic Study, pp. 45-104. Edited by N. J. W. Kreger-van Rij. Amsterdam: Elsevier.

Weijman, A. C., Rodrigues de Miranda, L. \& van der Walt, J. P. (1988). Redefinition of Candida Berkhout and the consequent emendation of Cryptococcus Kutzing and Rhodotorula Harrison. Antonie van Leeuwenhoek 54, 545-553.

White, T. J., Burns, T., Lee, S. \& Taylor, J. (1990). Amplification and sequencing of fungal ribosomal RNA genes for phylogenetics. In PCR Protocols. A Guide to Methods and Applications, pp. 315-322. Edited by M. A. Innis, D. H. Gelfand, J. J. Snisky \& T. J. White. San Diego, CA: Academic Press.

Xu, J., Saunders, C. W., Hu, P., Grant, R. A., Boekhout, T., Kuramae, E. E., Kronstad, J. W., Deangelis, Y. M., Reeder, N. L. \& other authors (2007). Dandruff-associated Malassezia genomes reveal convergent and divergent virulence traits shared with plant and human fungal pathogens. Proc Natl Acad Sci U S A 104, 18730-18735.

Zimmer, C., Platz, T., Cadez, N., Giffhorn, F. \& Kohring, G. W. (2006). A cold active (2R,3R)-(-)-di-O-benzoyl-tartrate hydrolyzing esterase from Rhodotorula mucilaginosa. Appl Microbiol Biotechnol 73, 132-140. 